\title{
90 years of perseverance and achievements in biological education and research
}

\author{
CHANG ZengYi \\ School of Life Sciences, Center for Protein Science, Center for the History and Philosophy of Science, Peking University, \\ Beijing 100871, China
}

Received October 27, 2015

Citation: Chang ZY. 90 years of perseverance and achievements in biological education and research. Sci China Life Sci, 2015, 58: 1053-1054, doi: $10.1007 / \mathrm{s} 11427-015-4964-7$

This special issue commemorates the 90th anniversary (1925-2015) of Peking University's School of Life Sciences. As one of China's centers for education and research in biological sciences, the school's past 90 years have been eventful, ranging from times of prosperity to periods of war and chaos, with numerous outstanding students launching distinguished careers as educators and researchers in biology and other disciplines, both within China and worldwide.

Six articles have been contributed by representative former undergraduate Peking University life science students (as well as from Dr. Yu HongTao, who graduated from Peking University School of Chemistry and Molecular Engineering). The first article provides a brief review of the School's history as seen by two alumni, Prof. Xu ZhiHong (who studied at the School from 1959 to 1965, served as Peking University's president from 1999 to 2008) and Prof. Zhu ZuoYan (who studied at the School from 1959 to 1965 , and is currently serving as the Editor General for both the Science China series and Science Bulletin) [1]. The next six articles cover a wide spectrum of biological science research areas, including RNA modifications (contributed by the group led by Dr. Chen XueMei, who studied at the School from 1984 to 1988, and is a member of the US National Academy of Sciences and an HHMI investigator at the University of California, Riverside) [2], innate immunity (contributed by the group led by Dr. Wu Hao [3], who

email: changzy@pku.edu.cn studied at the School from 1982 to 1985 , and is a member of the US National Academy of Sciences and the Asa and Patricia Springer Professor at the Harvard Medical School), lipid biology (contributed by Dr. Han Min, who studied at the School from 1978 to 1982, and is an HHMI investigator at the University of Colorado at Boulder) [4], synapse formation and axon regeneration (contributed by Dr. Jin YiShi, who studied at the School from 1980 to 1984, and is an HHMI investigator at the University of California, San Diego) [5], sister chromatid cohesion during the mitotic cell cycle (contributed by Dr. Yu HongTao, who studied at the Peking University School of Chemistry and Molecular Engineering from 1986 to 1990, and is an HHMI investigator at the University of Texas Southwestern Medical Center) [5], and functional genomics (contributed by Dr. Deng XingWang, who studied at the School from 1978 to 1982, and is a member of the US National Academy of Sciences and currently a professor at Peking University).

I greatly appreciate the kind assistance of Professors $\mathrm{Wu}$ Hong (current Dean of the School), Rao Yi (former Dean of the School), Xu ZhiHong (former President of Peking University), Zhu ZuoYan (Editor General for both the Science China series and Science Bulletin), Han Min (an HHMI investigator at the University of Colorado at Boulder), Wang ShiQiang (a vice Dean of the School), and Tom Kellie (of the University of the Chinese Academy of Sciences) as well as all the authors who contributed to this Science China Life Sciences special issue. 
1 Xu ZH, Zhu ZY. Celebrating 90 years of Peking University School of Life Sciences (1925-2015). Sci China Life Sci, 2015, 58: 1055-1056

2 Song JB, Mo BX, Chen XM. Uridylation and adenylation of RNAs. Sci China Life Sci, 2015, 58: 1057-1066

3 Qiao Q, Wu H. Supramolecular organizing centers (SMOCs) as signaling machines in innate immune activation. Sci China Life Sci, 2015, 58: 1067-1072

4 Min H. Twists and turns-How we stepped into and had fun in the "boring" lipid field. Sci China Life Sci, 2015, 58: 1073-1083
5 Jin YS. Unraveling the mechanisms of synapse formation and axon regeneration: the awesome power of $C$. elegans genetics. Sci China Life Sci, 2015, 58: 1084-1088

6 Ge Zheng G, Yu HT. Regulation of Sister Chromatid Cohesion during the Mitotic Cell Cycle. Sci China Life Sci, 2015, 58: 1089-1098

7 Zhen G, Zhang, L, Du YA, Yu RB, Liu XM, Cao FR, Chang Q, Deng $\mathrm{XW}$, Xia M, He H. De novo assembly and comparative analysis of root transcriptomes from different varieties of Panax ginseng C. A. Meyer planted in different environments. Sci China Life Sci, 2015, 58: 1099-1110

\section{Biographical Sketch}

Chang ZengYi received his B.S. degree in Biology in 1984 from East China Normal University (Shanghai, China). He was then accepted as a graduate student of the then Shanghai Institute of Biochemistry, Chinese Academy of Sciences before being selected as a CUSBEA (China United States Biochemistry Examination and Application) fellow to pursue his Ph.D.

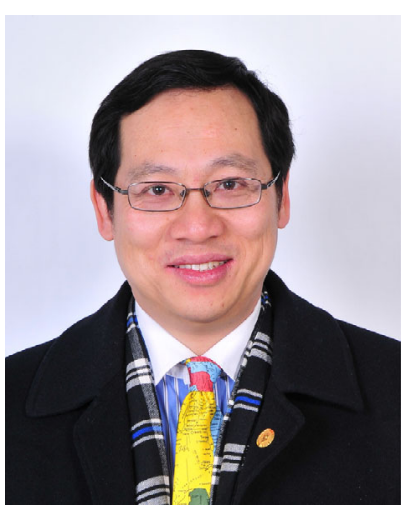
studies at the Department of Biochemistry, Baylor College of Medicine (Houston, USA). In 1992, he received his Ph.D. in biochemistry and afterwards did his post-doc training at the Howard Hughes Medical Institute (1992-1995). In 1996, he became an associate Professor at Tsinghua University (Beijing, China) and was promoted to full professorship in 1998. He moved to Peking University in 2003 where he currently serves as the director of the Center for Protein Science (2005-present), and was the Vice-Dean of the School of Life Sciences (2007-2013). He is currently the President-elect of the Federation of Asian and Oceanian Biochemists and Molecular Biologists (FAOBMB), the Past-President of the Asia Pacific Protein Association (APPA) and a vice President of the Chinese Society of Biochemistry and Molecular Biology. He is currently also serving as the executive vice Editor-in-Chief of Science China Life Sciences and an Editor of Biochemical and Biophysical Research Communication, an editorial board member of Protein Science. He also served as an editorial board members for the Journal of Biological Chemistry and IUBMB Life, among others. His laboratory explores the functions and mechanisms of such proteins as molecular chaperones and proteases in the quality control of proteins under stress conditions or during their biogenesis (especially membrane proteins including the ATP synthase) in living cells. His lab also seeks to understand the molecular mechanism of dormancy (e.g., bacterial persister). He has published more than 80 papers since becoming an independent PI in China.

Open Access This article is distributed under the terms of the Creative Commons Attribution License which permits any use, distribution, and reproduction in any medium, provided the original author(s) and source are credited. 